\title{
STRAH, ŽUDNJA, HISTERIJA: BILJEŠKE UZ JEDAN ZAPISNIK SA SUĐENJA VJEŠTICAMA
}

Izvorni znanstveni članak Primljeno: 16. 2. 2018. Prihvaćeno: 12. 3. 2018 DOI: $10.15176 /$ vol55no110 UDK 398.47(497.5)(091)"17" 133.4-055.2(497.5)(091)"17"

\author{
NATAŠA POLGAR \\ Institut za etnologiju i folkloristiku, Zagreb
}

\begin{abstract}
U tekstu autorica daje uvid u povijest jednog smjera historiografskih i antropoloških istraživanja masovnih progona vještica koji ih razmatra kao psihopatološki fenomen, odnosno razdoblje ranoga novoga vijeka smatra se dobom ludila - histerije, masovne histerije, fantazija. Takva se istraživanja nastavljaju na tradiciju medicinskih, neuroloških, psihijatrijskih i psihoanalitičkih radova koji su započeli s psihopatologizacijom žena optuženih za vještičarstvo, u kojoj Charcot i Freud imaju važnu ulogu. Autorica potom na primjeru jednoga zapisnika sa suđenja vješticama na sudu u Križevcima i Zagrebu iz 1751. i 1752. razmatra histeriju kao specifičnu vrstu žudnje i straha u odnosu na dominantnu afektivnu politiku i afektivne atmosfere te upućuje na neodvojivu povezanost osobnih strahova i tjeskoba i društvene dinamike.
\end{abstract}

Ključne riječi: strah, histerija, žudnja, afektivna politika, afektivne atmosfere, vještice, Hrvatska, 18. stoljeće

Progoni vještica diljem Europe tijekom nekoliko stoljeća, zbunjujući u svojem trajanju i okrutnosti, u brojnim su historiografskim i antropološkim radovima tumačeni kao svojevrsna kriza i/ili posljedica predlogičkoga, iracionalnoga odnosno magijskoga mišljenja i doživljaja svijeta.' Takav je pogled na rani novi vijek iznjedrio uglavnom tijekom 20. i 21. stoljeća niz studija koje su, direktno ili indirektno, progonima vještica pristupile kao psihopatološkome fenomenu, kao odrazu ludila, panike, histerije i masovne histerije. Jedan od utjecajnijih britanskih povjesničara u 20. stoljeću H. R. Trevor-Roper u knjizi The Crisis of Seventeenth Century (1969), a posebno u poglavlju "The European Witch-Craze of the Sixteenth and Seventeenth Century" te u nešto ranije objavljenome tekstu, "Witches and Witchcraft: An Historical Essay" iz 1967, vjerovanje u vještice smatra "fantazijom planinskih seljaka", "poremećajima psihotičke naravi” te "ženskom histerijom”. U oba rada ukazuje na

${ }^{1}$ Ovaj je rad sufinancirala Hrvatska zaklada za znanost projektom "Naracije straha: od starih zapisa do nove usmenosti", IP-2016-06-2463. 
najmanje dva paralelna i prema njemu odvojena procesa koja su se zbivala tijekom masovnih progona u Europi: na eliminaciju političke i ideološke opozicije ili konkurencije koja je dolazila "odozgo" te na različite poremećaje psihičke strukture koji su generirali strah i fantazije, a dolazili su od puka, to jest "odozdo". Premda su njegove teze o paralelnim, ali odvojenim procesima doživjele i osporavanja i revizije, teza o psihopatološkim strukturama subjekata i masovnoj histeriji u ranome novom vijeku kao glavnim generatorima progona dobila je svoje odvjetke u brojnim radovima sljedećih pedesetak godina, koji je često sugeriraju već samim naslovom, pojmovima poput witchcraze ili pak Hexenwahn. ${ }^{2}$ I jedan i drugi pojam pretpostavljaju neku vrstu zaluđenosti, manije i straha zbog kojih su procesi pokretani, ili koje se pak instrumentaliziralo u druge, najčešće političke svrhe. Jednako tako, i neke studije kojima nisu u fokusu konstrukcije vještica i njihovi progoni, nego pak povijest društvenoga i diskurzivnoga konstruiranja i reprezentacije ludila, poput Foucaultovih predavanja o abnormalnosti, ili knjige Roya Portera, Madness. A Brief History, između ostalih, naglašavaju da su u temeljima progona psihičke devijacije te da je tek prosvjetiteljsko ukazivanje i korigiranje patologije vjerskoga ludila (i/ili zanosa) rezultiralo zaustavljanjem procesa te adekvatnijom medicinskom skrbi o psihički nestabilnima i bolesnima, ponajprije ženama (Porter 2002: 5; 32-33).

\section{HISTERIJA I VJEŠTICE}

No eksplikacijski model da je vjerovanje u vještice zapravo simptom psihičkih bolesti, ponajprije histerije, nema svoje izvorište $u$ historiografskim ili antropološkim istraživanjima, dakako, nego pak u medicinskima još za ranoga novog vijeka, ${ }^{3}$ a u 19. i 20. stoljeću u neurološkim, psihijatrijskim te psihoanalitičkima. Upravo su Charcotova, ${ }^{4}$ a potom i Freudova ${ }^{5}$

${ }^{2}$ I witchcraze u engleskome govornome području i Hexenwahn u njemačkome sugestivno upućuju na ludilo, zaslijepljenost, maniju i strah povezane s vješticama, a koji se podjednako mogu odnositi i na tužitelje i na optužene, no i na političke i društvene sustave koji takvim vjerovanjima daju okvir. Popis radova s navedenim ključnim riječima u naslovu preopsežan je da bih ga ovdje navodila te stoga upućujem na tekst Erica H. Midelforta iz 2011., "Witch Craze? Beyond the Legends of Panic", u kojemu ih autor izdašno citira.

3 Već su autori iz "skeptične tradicije" demonološko-teoloških rasprava u doba masovnih progona poput nizozemskoga liječnika Johanna Weira, Britanca Reginalda Scotta i dr. naglašavali da dijelovi vještičjega imaginarija ili pak ekstatičkih stanja odgovaraju simptomima bolesti poput histerije, melankolije, megalomanije ili epilepsije, za koje se vjerovalo da češće pogađaju žene, i koje je potrebno adekvatno medicinski liječiti, a ne sankcionirati (usp. Elmer 2007: 37; Porter 2002: 25-31).

${ }^{4}$ Usp. Charcot, Jean-Martin i Paul Richer (1887). (Knjiga je dostupna na https://archive.org/stream/ lesdmoniaquesdaOOrichgoog\#page/n5/mode/2up. Više o neurološkim istraživanjima histerije Charcota i suradnika u Didi-Huberman (2003).

${ }^{5}$ Freud, kao i Charcot od kojega je učio, isprva je histeriju smatrao neuropatologijom da bi kasnije usmjerio fokus na istraživanje psihopatologije. Tako je nakon Studija o histeriji iz 1895. napisanih s neurologom Josefom Breureom objavio radove koji napuštaju neurološko-anatomske temelje i okrenuti su psihoanalizi, odnosno razvijanju teorije nesvjesnoga poput Fragmenta analize jednog slučaja histerije iz 1901., kasnije radova "Bilješka o nesvjesnom u psihoanalizi" iz 1912. ili "Potiskivanje" iz 1915., a koji se također dijelom temelje na izučavanju histerije (Ricoeur 2005: 89, 95). 
istraživanja histerije kao bolesti s historijskim kontinuitetom i simptomatologijom ${ }^{6}$ dala temelj prvo za etiologiju bolesti, a potom i za neke od ključnih pojmova psihoanalize poput artikuliranja nesvjesnog, mehanizma žudnje, terapije razgovorom, definicije potiskivanja i dr. (usp. Micale 1995). U pismu iz 1897. upućenom Wilhelmu Fliessu Freud uspoređuje iskaze žena optuženih za vještičarstvo s pričama histeričnih klijentica:

Što bi kazao kada bih ti rekao da je cijela moja nova povijest histerije znana i obznanjena stotinama puta prije nekoliko stoljeća? Sjećaš li se da sam oduvijek govorio da je teorija srednjega vijeka i crkvenih sudova o [demonskim] opsjednutostima identična našoj teoriji stranoga tijela i cijepanja svijesti? No zašto je vrag koji je opsjeo te nesretnice najčešće općio s njima na tako odvratan način? Zašto su njihova priznanja dobivena mučenjem tako slična izjavama mojih pacijenata pod psihijatrijskom paskom??

$\mathrm{U}$ istome pismu Freud iznosi mišljenje da su vještice, jednako kao i histerične žene, zapravo pripovijedale o vlastitim sjećanjima na djetinjstvo, no transponirajući ih u fantazije. Premda Freud izjednačuje progone vještica sa slučajevima opsjednutosti i smatra ih srednjovjekovnim fenomenima, što dakako nije točno, njegovo pozicioniranje izvorišta predodžbi o vješticama baš kao i simptoma histerije u registar nesvjesnoga, ostavilo je traga ne samo u temeljima psihoanalize nego i u (psiho)historiografiji i antropologiji, prvenstveno medicinskoj.

lako su im mnoge feminističke kritičarke kasnije zamjerale mizoginiju i patologizaciju ženskosti, a neke ih čak uspoređivale s ranonovovjekovnim egzorcistima i egzekutorima (Overd 1992: 124, prema Ferber 1997: 121) te iako je histerija u 20. stoljeću nestala s popisa psihosomatskih poremećaja, ${ }^{8}$ Charcotova i Freudova istraživanja i histerije i povijesti vještičarstva potaknula su brojne rasprave i razrade različitih aspekata u različitim disciplinama tijekom 20. i 21. stoljeća, od lacanovske i postlacanovske psihoanalize, kulturalnih studija, sociologije, književne teorije itd. (više u Micale 1995).

No, za reinterpretaciju, dijelom i dekonstrukciju, čitanja histerije kao ključne medicinske metafore za žensko stanje, a potom i za Freudova tumačenja ženskih priznanja vještičarstva isključivo kao slučajeva histerije zaslužni su prvenstveno radovi feminističkih kritičarki poput Hélène Cixous (1976), Catherine Clément (1979) i Luce Irigaray (1974). One su se vratile histeriji kako bi ukazale i propitale načine isključivanja ženskoga subjektiviteta iz

${ }^{6}$ Simptomi histerije bili su zanimljivima jer su vidljivi i tjelesni, a uključivali su grčenje, nesvjesticu, povraćanje, gušenje, jecanje, smijanje, paraliziranost dijelova tijela te brze izmjene emocionalnih stanja, što se tradicionalno asocira sa ženskom prirodom (prema Matijašević 2005: 831).

7 Freud, Sigmund, 1953. - 1974. "Report on My Studies in Paris and Berlin”. [1886.] The Standard Edition of the Complete Psychological Works of Sigmund Freud, 24 sv. Prir. i prev. James Strachey et al. London: Hobarth, 1: 11. (nav. prema Midelfort 2002: 209), prijevod N. P.

${ }^{8}$ Anouchka Grose navodi kako je iz prvoga Dijagnostičkoga i statističkog priručnika mentalnih poremećaja koji je 1952. objavilo Američko psihijatrijsko društvo histerija nestala s popisa, no zapravo je zamijenjena konverzijskom reakcijom. U drugom izdanju iz 1968. ponovno se pojavljuje i to kao "histerična neuroza", a od 1980. u potpunosti je zamijenjena konverzijskim poremećajem i histrionskim poremećajem ličnosti (Grose 2016: XVI). Danas je histerija uglavnom zamijenjena ili s borderline poremećajem ili pak histrionskim poremećajem ličnosti, no u teorijskoj literaturi ali i kliničkoj praksi ponajprije lacanovske psihoanalize i dalje ima prominentno mjesto pod prvotnim nazivom. 
muške kulture, odnosno kako bi podcrtale da povijest histerije i povijest progona vještica imaju važnu dodirnu točku jer svjedoče o kulturalnom kodiranju ponajprije ženske normalnosti. I vještice u ranome novom vijeku i histerične pacijentice u 19. te početkom 20. stoljeća imale su važnu društvenu ulogu jer ih se upravo zbog navodnih transgresija i subverzija društvenih normi koristilo za uspostavljanje normativa (ne)normalnosti, odnosno za uspostavljanje reda i novih modela ženstva (usp. Roper 2006).

Luce Irigaray histeričnu ženu naziva mystérique te smatra da je mistički diskurs jedini prostor u povijesti zapada u kojem žena govori i djeluje javno u patrijarhalnom okviru, odnosno smatra da mistična iskustva, kao i histerija nekoliko stoljeća kasnije, nude ženama mogućnost da postanu prisutne i vidljive, odnosno da istraže neke aspekte vlastite žudnje i užitka (Irigaray 1985: 191-202). Tome se nizu mističarki i histeričarki mogu pridodati i iskazi žena optuženih za vještičarstvo kao i onih koji ih optužuju, koji tek na ispitivanjima i suđenjima dobivaju priliku u javnome prostoru govoriti o vlastitome životu, fantazijama, pa i emocijama koje su do sada rijetko u studijama o progonima vještica bile u fokusu, bez obzira na to koje im je disciplinarno polazište. ${ }^{9}$

\section{AFEKTIVNE POLITIKE, AFEKTIVNE ATMOSFERE I EMOTIVNE PRAKSE: PROGONI VJEŠTICA}

Ako se odmaknemo od analize navodnih psihopatoloških struktura zajedničkih histeriji i priznanjima vještičarstva te fokus usmjerimo na analizu naracija emocija i afekata ${ }^{10} \mathrm{u}$ oba diskursa, možemo uočiti da su upravo snažne i "nedopuštene", neprihvatljive emocije, kodirane odnosno prevedene $u$ jezik te izgovorene pred publikom i za publiku, odnosno svjedoke, zajedničke i histeriji i vještičjem diskursu. Još je 70-ih godina prošloga stoljeća Norbert Elias zamijetio da društva stvaraju "emotivne hijerarhije" pa se tako neke emocije u nekom kontekstu smatra prihvatljivima, odnosno znakovima kultiviranosti i razumnosti, dok su druge kvalificirane kao neprihvatljive, negativne, kao znakovi slabosti ili ludila te koje zahtijevaju sankcioniranje ili korekciju (Elias 1978 i 1982; Frevert 2011: 87-124). Naracije emocija u histeriji i vještičjem diskursu tako su istodobno iskaz ženskoga nastojanja (ili prisile) na socijabilnost, ali i pobune protiv zadanih uloga i pozicije (usp. Bronfen 1998), no s nekim ključnim razlikama. Prva i najočitija je kontekst pripovijedanja - iskazi žena optuženih za vještičarstvo dani su pod prisilom, kao dio torturalne procedure i prema zadanim formulama, često $u$ obliku odgovora na specifična pitanja propisana zakonskim

\footnotetext{
${ }^{9}$ Iznimku čini nedavno objavljeni zbornik, Emotions in the History of Witchcraft iz 2016. koji su uredili Lara Kounine i Michael Ostling, u kojemu se autori bave različitim afektima, emotivima, emotivnim režimima i praksama vezanim uz vještičarstvo, od optužbi, suđenja, demonoloških tekstova do vizualnih reprezentacija.

${ }^{10} \mathrm{U}$ tekstu pod afektima podrazumijevam konceptualizaciju koja ne razdvaja strogo emocije od afekata, nego ih pak razumije kao karakteristiku emocija da dotaknu, djeluju, izazovu reakciju kod Drugoga. Takva se konceptualizacija oslanja na freudovsko-lacanovsko psihoanalitičko razumijevanje pojma koje je preuzela i razradila i Sara Ahmed u Cultural Politics of Emotion.
} 
odredbama i s teološkom pozadinom, i koja nisu smjela ostati neodgovorena jer je to značilo produžavanje torturalne agonije. Druga se razlika, koja je i predmetom ovoga rada, odnosi na afektivnu atmosferu u kojoj emocije nastaju, odnosno koja potiče iskazivanje nekih emocija i sankcioniranje drugih $u$ određenom sociokulturnom kontekstu, tj. u razdoblju progona vještica. Također, razlika je i u afektivnim politikama koje kreiraju afektivne atmosfere ${ }^{11}$ unutar nekoga društva ili zajednice, a koje ću razmatrati ne toliko preko afekata nego preko cirkulacije objekata emocija, atmosfere u kojoj vještice postaju objektima koji asociraju strah, mržnju i prezir. Na primjeru jednoga zapisnika sa suđenja vješticama u Križevcima i Zagrebu tijekom 1751. i 1752., dakle pred sam kraj masovnih progona, ${ }^{12}$ namjeravam analizirati emotivni diskurs osobe koja pokazuje simptome histerije i koja pokreće cijeli proces optužujući nekoliko žena da su vještice. ${ }^{13}$ Preciznije, nastojat ću utvrditi koliko je u njezinoj naraciji žudnja, koju lacanovska psihoanaliza i psihoanalitička kritika smatraju središnjim pitanjem histerije, kodirana jezikom u naraciju straha od vještica i to metonimijskom zamjenom jednoga objekta drugim, odnosno zanima me koliko su žudnja i strah kao osobne emocije u navedenome slučaju zapravo transpersonalne i oblikovane afektivnim atmosferama i afektivnim politikama.

Brojne studije emocija (ili povijesti emocija) naglašavaju kako je osobne, individualne naracije emocija teško razumjeti izvan širega društvenog afektivnog konteksta i djelatnih procesa (usp. Stearns i Stearns 1985; Reddy 2001; Frevert 2011; Plamper 2015), odnosno kako ističe Sara Ahmed, afektivni su procesi uvijek $u$ aktivnom, pregovaračkom i intenzivnom odnosu s ideologijama i konceptualizacijama društveno prihvatljivoga iskazivanja emocija, odnosno njihova sankcioniranja (usp. Ahmed 2014). To bi značilo da emocije nisu samo psihološka i tjelesna stanja pojedinca, nego i društvene i kulturne prakse koje su u kontinuiranom međuodnosu: emocije su potaknute objektima, stvarnima ili imaginarnim,

\footnotetext{
${ }^{11}$ Premda pojam afektivne atmosfere preuzimam od Bena Andresona (2009) jer ga smatram iznimno korisnim u opisivanju učinaka afektivnih politika, s njegovim se pojašnjenjem ipak ne mogu dokraja složiti. Naime, on tvrdi kako su "[a]tmosfere [su] vrsta iskustva koje se pojavljuje prije i istodobno formiranju subjektiviteta, preko ljudskih i ne-ljudskih materijalnosti i između distinkcija subjekt - objekt” (Anderson 2009: 78), što bi značilo da afektivne atmosfere ne nastaju niti su dotaknute subjektima koji su u njih uronjeni, a niti podliježu reprezentacijama ili subjektivnim interpretacijama. Takvo atribuiranje afekata kao ne samo nadosobnih i transpersonalnih nego i ne-osobnih sila koje nastaju neovisno o ljudskim i (ne-ljudskim) subjektima smatram nedostatno razrađenim, pa i neuvjerljivim, jer u krajnjoj konzekvenci jest poništavanje samoga subjektiviteta. O kritici Andersonova pojma afektivne atmosfere više u Wetherell (2013).

12 Premda još od 13. stoljeća u Hrvatskoj postaje pisani zakoni i odredbe protiv vještičarstva, koji su vjerojatno tek pisana kodifikacija starijih običajno-pravnih propisa, razdoblje masovnih progona vještica u Hrvatskoj započinje potkraj 17. stoljeća, točnije 1699. i traje sve do sredine 18. stoljeća kada ih carica Marija Terezija stavlja pod svoju nadležnost, iako ih ne ukida. Pod masovnim se progonima podrazumijeva razdoblje u kojem je sekularna vlast u potpunosti prihvatila teološku definiciju vještičarstva te je uvrstila u zakon, primjena torture postala je dio uobičajenoga istražnoga postupka i koja je trajala sve dok osumnjičena osoba ne bi priznala zločin ili preminula, a novi su postupci pokretani nakon što bi mučena osoba "odala" imena drugih sudionika/ica u vještičarstvu. Upravo je prokazivanje bilo glavnim i jedinim dokaznim postupkom za pokretanje procesa koji su gotovo redom završavali smrtnom presudom. Više o dva razdoblja progona vještica u Hrvatskoj u Bayer (1982: 215-302).

${ }^{13}$ Prvotno je zapisnik cijeloga procesa objavio I. K. Tkalčić u "Izprave o progonu vješticah u Hrvatskoj" 1892. u Starinama, knjiga XXV: 76-100, Zagreb: JAZU, a potom je prijevod spisa na hrvatski objavio i Vladimir Bayer u Ugovoru s đavlom, koji ću navoditi u ostatku teksta.
} 
odnosno potaknute su značenjem, interpretacijom tog objekta za pojedinca, a koje je kulturno i društveno uvjetovano. Utoliko emocije, koje su i osobne i intencionalne, upućuju i na načine kako dolazimo u doticaj, kontakt s objektima i Drugima te kakav sud, mišljenje o njima potom donosimo, kakvu (tjelesnu) reakciju izazivaju i kako se taj sud i reakcija, emocija potom reflektiraju ponovno na tijelo, a zatim i društvo u kojem su nastale ili su u njemu proizvedene. Interkorporalnost emocija, koju naglašava Ahmed, postaje tako temeljem emotivnih odnosno afektivnih zajednica, koje nekim oblikom društvenoga ugovora nekim tijelima pridaju određena značenja. $U$ ovome radu zanimat će me upravo taj trenutak - kada društvenim ugovorom i zakonskim odredbama - neka tijela, ona vještičja, postaju opasnima, zastrašujućima i stranima te kako blizina tih tijela/toga tijela oblikuje naracije o vlastitome životu, emocijama i ponajviše žudnji. U doba masovnih progona tijelo vještice doživljava se kao strano i zastrašujuće jer je drukčije od ljudskoga: posjeduje moći i obilježja koje "obična", "normalna" tijela nemaju a s pomoću kojih može nanijeti štetu. Tijelo tako doslovno postaje znakom opasnosti, na čije je značenje fokusirana istražna i torturalna procedura koju pak regulira afektivna politika ovjerovljena zakonskim aktima: primjerice, cijeli dio Kriminalne prakse posvećen je upravo procedurama ispitivanja tijela, odnosno obilježen je strahom od vještica. ${ }^{14}$

U takvoj afektivnoj atmosferi straha i tjeskobe, ili prije - atmosferi u kojoj su javna iskazivanja straha i tjeskobe bila društveno i ideološki podržana ako su im objektima bile vještice, histerični diskurs vlastiti objekt oko kojega je sazdana neuroza i protiv kojega je usmjerena pobuna zamjenjuje kolektivno prihvatljivim, dijeljenim i kolektivno potaknutim, vješticama. Niz "privatnih" emocija čije je prikazivanje i pripovijedanje bilo neprihvatljivo, neprilično ili sankcionirano $u$ javnim naracijama biva zamijenjeno pripovijedanjem o emocijama koje su dopuštene, shvatljive i koje jačaju odnose unutar afektivne zajednice, o čemu svjedoči i slučaj tužiteljice Marijane Frajt.

\section{HERMENEUTIKA TIJELA: SLUČAJ MARIJANE FRAJT}

Iz zapisnika procesa vođenoga od 8. kolovoza 1751. do 4. svibnja 1752. na Sudu Zagrebačke županije u Križevcima i kasnije Zagrebu doznajemo da otac Marijane Frajt (u zapisniku su i varijante imena, Marija i Mara) podnosi tužbu protiv Marijane Vugrinec, optužujući je da je vještica koja je narušila tjelesni integritet njegove kćeri. Tijekom ispitivanja optužnica se proširuje na još tri žene, Magdu Brcković (svekrvu Marijane Frajt), Maru Brukec i Maru Fućkan, a premda su spomenuta i dva muškarca kao pripadnici vještičje skupine koja je mučila i napadala tužiteljicu - suprug Marijane Frajt, Brcko Smerdić, i njegov otac -

${ }^{14}$ Kriminalna praksa ili Praxis criminalis latinski je prijevod zakonika o kaznenom postupku kralja Ferdinanda III. za Donju Austriju, a važio je kao pisani dokument običajnoga prava i za Ugarsku, dakle i Hrvatsku i Slavoniju te je 1697. uvršten u Zbornik prava Ugarske i pripojenih joj zemalja. Istoobno je bila kazneni zakonik i zakonik o kaznenom postupku, a u članku 60., stavka 2 i 3 te dijelom 4 propisuje se istražni postupak nad tijelom vještice. Cijeli tekst Kriminalne prakse u Bayer (1982: 567-571). 
optužnica protiv njih nije podignuta niti u zapisnicima ima traga o njihovom ispitivanju kao osumnjičenih nego pak isključivo kao vjerodostojnih svjedoka. ${ }^{15}$ Afektivna atmosfera i nepisani zakoni očito su smatrali isključivo ženska, vještičja tijela opasnima, onima koja mogu nanijeti štetu. U pismu podžupana Križevačke županije Ivana Saića upućenom podžupanu Zagrebačke županije od 10. prosinca 1751. kao pojašnjenje procesa stoji opis maleficija, odnosno tjelesnoga oštećenja:

Tu su sirotu snahu vještice toliko uzele da si desnom nogom i rukom nije mogla pomoći ni koristiti. Jer i noga joj je i ruka bila toliko skvrčena da joj otac nije s družinom rastezao prste od dlana, pa joj komad drva unutra metnuo, bili bi joj prsti zajedno s dlanom sagnjili. Utekao se k meni, moleći za pomoć i kazao je da je te opake žene stalno napadaju i među se zovu. (Bayer 1982: 683)

U ostalim pismima i daljnjim ispitivanjima na sudu dodatno se pojašnjavaju tjelesni simptomi maleficija koji umnogome odgovaraju simptomima histerije, odnosno histeričnoj strukturi, ${ }^{16}$ koji su uključivali lokaliziranu paralizu, konvulzije, afaziju, "putujuće" bolove pa sve do halucinacija i fantazmi. $U$ istome pismu Saić bilježi da je pozvao na ispitivanje U Svetu Jelenu suca Križevačke županije, Đuru Petkovića, na čijem je posjedu osumnjičena Vugrinec služila, tužiteljicu Marijanu Frajt, njezina oca, potom njezina supruga s roditeljima, a naposljetku i osumnjičenu Mariju Vugrinec. No njihovo je sučeljavanje dovelo Marijanu Frajt u stanje teške uznemirenosti i straha, nakon čega je izgubila sposobnost govora i najvjerojatnije se onesvijestila:

Kad je došlo do suočavanja i snaha stala pripovijedati kako se s njome postupalo i što su baba Marica, svekrva i muž rečene snahe htjeli da ona načini božićne noći kada se išlo k ponoćki i od ponoćke kući dolazilo, pristupila je baba Marica k snahi koja je sjedila na stocu i stala je zubima nešto gristi i oštro i uporno snahu u oči gledala govoreći: "Ta jesam li ja to govorila?" Snaha potvrđuje da jest. Nadalje, pitam ja snahu neka sve kaže što zna. Ali je snaha počela plaho gledati mašući rukom da ne može više govoriti. I ni riječi nije mogla progovoriti, nego je, preplašena i u strahu, obamrla pred nama na tle pala. (Bayer 1982: 683-684)

Slično se ponovilo i na sudskoj raspravi 15. prosinca 1751. održanoj ovoga puta u Zagrebu kada je pozvana svjedočiti žrtva Marija[na] Frajt, i na kojoj se otkrivaju osobniji, intimniji detalji njezina života, odnosno zbivanja koja su prethodila maleficiju/histeričnim epizodama, i čije je pripovijedanje detaljno zabilježeno, premda u trećem licu singulara:

${ }^{15}$ Kriminalna praksa iz 1697. koja sadrži propise o postupcima protiv čarobnjaštva odnosno vještičarstva, rodno je neutralna, to jest izrijekom dopušta mogućnost da zločin mogu počiniti podjednako muškarci kao i žene, posebno članak 60. (Bayer 1982: 567).

${ }^{16}$ lako se u ranim psihoanalitičkim tekstovima poput Studija o histeriji iz 1895. te u "Odlomku analize jednog slučaja histerije" iz 1905. Freud bavio aspektima histeričke strukture, tek je u kasnijem radu "Ženskost" utvrdio da je središnje pitanje bolesti "Što žena želi?" te tako smjestio histeriju u područje seksualne politike i seksualnog identiteta (prema Borossa 2003: 9-10). Lacan, nastavljajući se na Freuda, objašnjava histeriju preko žudnje Drugoga koja je uvijek kolektivna, a posebno u seminaru iz 1958/1959. naslovljenom Žudnja i njezino tumačenje. 
Godine 1750., oko blagdana sv. Blaža, udala se za Brcka Smerdića i došla je u njegovu kuću. Tu je po izmaku nekog vremena počeo izjaviteljicu spomenuti njen muž sa svekrvom Magdom Brcković i sestrom njenom Dorom (koja je i sada kod nje u službi) mamiti i nagovarati (da stupi) u družbu vještica. Ali ona je odbijala. Kada je gore navedena Marijana Vugrinec oko blagdana pohoda bl. dj. Marije 1750. godine, ušla kao služavka u rečenu kuću, navraćala je i ona, Marijana Vugrinec, izjaviteljicu u spomenutu družbu pobudama: da će imati više mlijeka, da će njeno žito svagdje biti bolje, što god će vidjeti da će biti njeno i drugim sličnima. I kad rečena izjaviteljica nije ni na koji način htjela da stupi u spomenutu družbu, navedena ju je Marijana Vugrinec na poticaj prije spomenutog muža (izjaviteljičina) u tri maha izbatinala. Pa kad to izjaviteljica nije mogla da podnosi, otišla je odanle u nedjelju iza Božića naprijed navedene 1750. godine i vratila se k svojim roditeljima. Ali ni tamo nisu prestali gore navedeni, pa i Marijana Brukec, da dolaze katkad noću, a nekad i danju, i navraćaju je u spomenutu družbu: da će joj lijepo biti, gostit će se, u kočiji će se voziti, a ubacivali su i prijetnje da će je, ako ne posluša njihova nagovaranja nožem zaklati ili je lišiti vida, ruku ili nogu. Pa tako joj se i dogodilo, naime kad je tekuće, 1751. godine, na dan sv. Blaža došao njen muž u kuću roditelja kamo se izjaviteljica bila vratila, one je večeri izjaviteljica kao na nečiju zapovijed izišla iz kuće i iznenada osjetila kako je nekakav snažni vjetar dunuo u nju i kako joj se u isti mah desna noga i ruka ukočila. I tamo je među mnogima nazočnim vješticama prepoznala one koje su gore navedene. One su je tamo također nagovarale i na pređašnji joj način prijetile (da bi ušla) u spomenutu njihovu družbu. Ali ona je lijevom rukom pograbila nekakav štap i vitlajući njime stala zamahivati, a usto je povišenim glasom podviknula i pobjegla u kuću. Tu je nekoliko puta podignuta s poda do stropa i o nj udarila. Njen otac, zaprepašten, počeo je ispitivati da kaže što je. Nato je muž izjaviteljičin koji je tamo bio prisutan dobacio: "Neće reći istinu". A kad je otac stalno poticao izjaviteljicu da priča, ponovio je muž da neće progovoriti i izjavio da je on već deset puta bio u takvoj prilici. Izjaviteljicu su položili i otac ju je počeo kaditi blagoslovljenim prahom. Međutim je izjaviteljici ostala ruka i noga ukočena sve do osmog dana mjeseca kolovoza iste godine, kada je naime kod Sv. Jelene bila suočena sa spomenutom Marijom Vugrinec. Kada je izjaviteljica prigodom toga suočenja u nazočnosti gospodina podžupana Ivana Saića i plemićkog suca Đure Petkovića htjela da ispriča način na koji su je gore navedeni pozivali u družbu vještica, iznenada je osjetila da je lišena dara govora i vidjela kako su je gore navedena Marija Vugrinec, svekrva njena i muž bacili licem na tle i ništa više nije mogla da progovori. Kad se to tamo dogodilo, stao je gospodin podžupan Saić prijetiti ondje nazočnoj Mariji Vugrinec i svekrvi izjaviteljičinoj, ako izjaviteljici ne povrate zdravlje. Ali Marijana Vugrinec ga je ozbiljno uvjeravala da ona to ne može učiniti, nego svakako (da bi mogla) kad bi je pustili kući njenoj. Konačno je izjaviteljica poslana u kolima sa spomenutom Marijanom Vugrinec u kuću u koju se udala. Ista Vugrinčevka ju je pustila da natraške uđe u kuhinju i tako skoči na ognjište, pa svoju nogu snažno utisne. Kad je to izjaviteljica učinila, Marijana Vugrinec je izvadila iz ladice ispod stola nekakovu mast i njome joj ruku namazala. Od tog mazanja ukočenost je popustila, a izjaviteljica je u ukočenim udovima osjetila neko škripanje sudarenih kostiju. Konačno je po uputi Marijane Vugrinec natraške skočila s ognjišta i kad je izlazila iz kuhinje vratilo joj se pređašnje zdravlje. Međutim, dok je pred sudom ispripovijedala što je naprijed navedeno i dalje bila ispitivana, dala je rukom znak da ne može govoriti i konačno se srušila na pod i tresla se tamo. No na neki se način ipak povratila k svijesti, pa je onda 
izjavila pred sudom da je naprijed navedene vještice muče. Kad je sud htio da pođe dalje u njenom ispitivanju, uvijek je ponovo padala u naprijed prikazano stanje. Pošto je to sud primijetio, otpuštena je odanle. Ali je ipak u toku svoga ispitivanja zapitana bi li htjela da se zakune na ono što je gore ispričala. I spremno je izjavila da će se zakleti. No zakleti se zbog navedenog događaja stvarno nije mogla. (Bayer 1982: 688-690)

Iz navedenoga zapisnika saznajemo dijelove faktične, ali i emotivne biografije Marijane Frajt: u dom svojega supruga Brcka Smerdića došla je nakon udaje, oko blagdana sv. Blaža, dakle oko 3. veljače 1750., u kojem ostaje sve do poslije Božića iste godine kada se vraća roditeljskoj kući. Odmah nakon vjenčanja počeli su je suprug, njegova majka i njezina sestra nagovarati da se pridruži vještičjoj družbi što je odbijala, a premda sama ne spominje (histerične) epizode iz toga razdoblja, odnosno paralizu ili afaziju, njezin suprug navodi da ih je bilo bar desetak. No, dolaskom Marijane Vugrinec u kuću Smerdićevih na blagdan Pohoda Blažene Djevice Marije, dakle 31. svibnja, napadi na Frajt postaju češći i uz sve više prijetnji, a kako je izjavila, čini se i da je njezin suprug triput zapovjedio sluškinji Vugrinec da je fizički kazni, odnosno istuče te nakon toga Frajt napušta kuću i odlazi u strahu svojim roditeljima. Jednako, izgleda da ni njezin brak s Brckom Smerdićem nije osobito funkcionalan ili zadovoljavajuć za mlađu ženu, što je moguće iščitati iz dijelova njezine naracije. No ni nakon bijega u sigurnost obiteljskoga doma napadi ne jenjavaju pa tako pripovijeda kako su je vještice posjećivale i nagovarale tijekom noći, ali i dana, a osobito je zanimljiva epizoda kada je 3. veljače 1751. njezin suprug dolazi posjetiti. Naime, te je večeri osjetila da mora izići iz kuće da bi je potom napale vještice (između mnogih prisutnih, i one koje je tužila), desna ruka i noga su joj bile paralizirane, a po povratku u kuću doživjela je i spazme cijeloga tijela, čemu su svjedočili njezin otac i suprug. Ruka i noga ostale su joj paralizirane sve do kolovoza iste godine kada joj je optužena Vugrinec magijskim radnjama "skinula čini", a svako pripovijedanje u sudnici o tim zbivanjima dovodilo ju je u stanje straha, konvulzija, afazije i potpune iscrpljenosti.

Njezina afektivno obilježena naracija je verbalna, no za razumijevanje histerije kao rada žudnje i straha od žudnje, kao i za razumijevanje metonimijske zamjene jednoga objekta drugim podjednako je bitna, ako ne i važnija, njezina tjelesna naracija. Tijelo tako postaje verbalnim instrumentom i preuzima pripovijedanje u onome trenutku kada Frajt osjeća da su određene emocije nedopustive, kada unutarnji konflikt ne može biti artikuliran te podliježe konverziji, odnosno zamjeni jednoga objekta (žudnje) drugim objektom, vješticama, koje pripadaju u društveno odobren, valoriziran objekt straha. Dugotrajna, u ovome slučaju višedesetljetna (pa i višestoljetna) proizvodnja vještica kao objekta straha omogućila je Frajt da ipak narativno uobliči dio vlastitih afektivnih stanja kodirajući ih, prevodeći ih u jezik.

Lucien Israël smatra kako je jezik histerika (ili jezik histerije) jedan od modusa komunikacije, pokušaj uspostavljanja odnosa s Drugim kako bi subjekt prenio poruku o prepoznavanju vlastita manjka ("nisam cjelovit/a"), no postizanje toga cilja obuhvaća pretvaranje svih strahova, tjeskoba i žudnji u somatske manifestacije i reprezentacije (Israël 1976). No taj je jezik nešto drukčiji jer je kodiran upravo zbog straha te omogućuje subjektu da u vlastitim, stvorenim okvirima sigurnosti "neproničnoga jezika" progovori o osobnim ali i kulturološki, 
društveno generiranim nezadovoljstvima, odnosno ponajprije o žudnji i strahu od njezina ne/ispunjenja. Ili, kako naglašava Bronfen, ono što histerik govori je poruka, i to o ranjivosti i krhkosti - simboličkoga (društvenih odnosa), identiteta (nesigurnost u rodna, etnička, klasna određenja), a ponajviše - o krhkosti i ranjivosti tijela (Bronfen 1998: xiii). Točnije, kod histerije tijelo i tjelesne manifestacije postaju porukom odnosno naracijom: naracija straha prevedena je u nevoljne pokrete - konvulzije ili pak u zaustavljenu sliku, paralizu, ili je pak radikalno zapriječena afazijom, trenutnom ali potpunom odsutnosti glasa i govora. Tako Marijana Frajt svaki put kada u sudnici ili u vlastitu domu počne verbalizirati nagovor odnosno poziv vještica da im se pridruži jest zaustavljena i priču pokušava nastaviti ili tijelom ili šutnjom, tišinom. No ni njeni trzaji niti njezina šutnja nisu pod njezinom kontrolom - već sama pomisao na izgovaranje prijetnje koje su joj upućivale vještice, ili - što je vjerojatno još važnije - na ponavljanje njihovih obećanja, aktivira somatsku reprezentaciju Drugoga. Naime, kako je to artikulirao Lacan, tijelo nikada nije samo u posjedu subjekta nego je i upisna ploha Drugoga, mjesto zaposjednutosti koje pokreće žudnja17 (usp. Verhaeghe 2001: 68-69). Takva je žudnja, koju Lacan definira kao metonimiju manjka bivanja ili manjka u biću (manque-à-être), organizirana oko imaginarne anatomije i slike fragmentiranoga tijela, a upravo je u histeriji od svih kliničkih struktura najjasnije prikazana struktura žudnje Drugoga i žudnje za Drugim: histerik prihvaća tuđu žudnju i s njome se identificira, no može je prihvatiti jedino pod uvjetom da on/ona nije i objekt te žudnje (Lacan 1966: 222).

Rad žudnje u histeriji moguće je pratiti i na slučaju Marijane Frajt, čiji se simptomi počinju manifestirati, a vrlo brzo i radikalno pogoršavati nakon vjenčanja i dolaska u suprugovu kuću. Trenutak kada ovjerovljeno bračnim ugovorom postaje objektom njegove žudnje i kada je njezina pozicija u simboličkome jasno određena "gubitkom" dijela vlastita subjektiviteta i/ili identiteta postajanjem objektom, odnosno redukcijom na objekt razmjene između oca i supruga, za Marijanu Frajt postaje i trenutkom kada tijelo preuzima naraciju. Na tragu feminističkih čitanja histerije (ponajprije L. Irigary), njezine se simptome može razmatrati i kao pobunu protiv dodijeljene pozicije, protiv simboličkoga kao dominantno patrijarhalne kulture, protiv očinske metafore, koja kulminira njezinim odlaskom iz suprugove kuće svega nekoliko mjeseci nakon vjenčanja. O krhkosti (ženskoga) identiteta mnogo govori i atribuiranje Marijane Frajt u sudskim dokumentima - premda udana za Smerdića, o njoj se govori i piše ili kao Marijani Frajt, čime je se i dalje određuje kao "vlasništvo" oca, ili pak kao o gotovo generičkoj snahi u pismima podžupana Saića ("Šaljem pred lice suda snahu koju su vještice bile uzele"; "Kad je došlo do suočavanja i snaha stala pripovijedati”, "Nadalje, pitam ja snahu neka sve kaže što zna"), ali i u iskazima drugih optuženih.

\footnotetext{
17 Žudnja je zapravo središnji koncept Lacanove teorije, i to ponajprije nesvjesna žudnja koju je moguće raspoznati tek nakon što je artikulirana odnosno stvorena jezikom. Žudnju Lacan strogo razlikuje od zahtjeva i potrebe: potreba je rezultat biološkoga instinkta koja kada je artikulirana postaje zahtjevom za zadovoljavanjem potrebe. No, dio potrebe nikada ne može biti zadovoljen, a taj dio je upravo žudnja, ona je višak nastao artikulacijom potrebe u zahtjev. Osim što je se ne može zadovoljiti, odnosno što je nastala iz ne-zadovoljenja, teško ju je i iskazati jezikom zbog temeljne "nekompatibilnosti između žudnje i govora" (Lacan 1966: 275). Ili kako pojašnjava Evans, "premda je istina o žudnji donekle prisutna u svakom govoru, govor nikada ne može artikulirati cijelu istinu o žudnji; kadgod se govorom pokuša artikulirati žudnju, uvijek je tu ostatak, višak, koji nadilazi govor" (Evans 1996: 61).
} 
Osim pokušaja da napuštanjem suprugova doma (što podrazumijeva i odustajanje od vlastite nove uloge) stabilizira vlastiti identitet, iz zapisnika je vidljivo da je njezin odlazak i čin pobune protiv nasilja, metaforičkoga, ali ponajprije fizičkoga jer je u nekoliko navrata Vugrinec instrumentalizirana da fizički kazni neposlušnu suprugu.

Elaine Showalter (1985) i Martha Evans (1991) smatraju kako se histeriju može interpretirati kao patološki odgovor na dodijeljene rodne uloge i osjećaj društvene nemoći, na nezadovoljstvo represivnim, kulturološki konstruiranim idealom ženstva, ponajprije poslušnošću i podložnošću muškarcima. Premda se lako složiti sa Showalter i Evans da je histerija odgovor, odnosno pobuna protiv zadanih uloga i osjećaja nemoći da im se u potpunosti izmakne, smatram kako nije nužno riječ o patološkome odgovoru nego o za subjekt jednom od mogućih odgovora na patologiju svakodnevice, tj. na društveni i ideološki kontekst u kojem se neke emocije i afekti nastoje prigušiti i disciplinirati. Suočavanje s neupitno neuspješnom pobunom Marijanu Frajt doslovno ostavlja bez glasa - njezina šutnja, odnosno nemogućnost govora je istodobno i vrlo jasan iskaz straha, baš kao što je paraliziranost njezine ruke simbolizacija nemogućnosti da se obrani od nasrtaja, a paraliziranost noge nemogućnosti da doista iskorači iz zadane joj uloge i pobjegne. (Histerično) tijelo i njegovi simptomi tako su postali zrcalom afekata koje se ne može drukčije iskazati, dijelom iz straha i pobune, a dijelom i stoga jer je, kako naglašava Lacan, žudnju nemoguće do kraja obuhvatiti jezikom.

\section{ŽUDNJA I NJEZINA METONIMIJA}

Kako je iz opisanih simptoma Marijane Frajt prilično razvidno da je riječ o histeričnoj strukturi, ostaje nam osvrnuti se na središnje pitanje histerije, a to je pitanje žudnje, te kako je žudnja povezana s metonimijskim zamjenama jednoga objekta (ili označitelja) drugim te $s$ afektivnom atmosferom straha.

Frajt koherentno pripovijeda o vlastitu životu, vjenčanju, odlasku od supruga, odnosima u obitelji, no svaki put kada dolazi do ključnoga trenutka - narativnoga uobličenja poziva u vještičje društvo ili njihovih prijetnji - ona doživljava konvulzije, paralizu i nestaje joj glasa te ne može nastaviti s pripovijedanjem. Napade vještica o kojima pokušava pripovijedati, pred kojima je nemoćna noću, dok im se danju ponekad uspijeva othrvati, možemo razumjeti kao fantazme, vizualne reprezentacije žudnje koja je zakrivena, odnosno kao slike "zamrznute" upravo na onome mjestu na kojemu bi se mogao raspetljati čvor oko kojega je žudnja sazdana (Evans 1996: 60). No, u histeriji žudnju se nastoji držati na uvijek istoj udaljenosti - ona ne samo da ne može biti zadovoljena, što je uobičajeni rad žudnje, nego i ne smije biti zadovoljena (Lacan 1960/1961: 294), ${ }^{18}$ a histerik je prihvaća jedino ukoliko nije objektom žudnje. Čini se da je čvorište histerije M. Frajt upravo u nagovoru vještica i

18 “Postoji nešto što joj je draže od vlastite žudnje - ona preferira da njezina žudnja ostane nezadovoljena, jer Drugi čuva ključ njezine tajnovitosti” (Lacan 2001: 294, 8. seminar). 
njezinim nastojanjima da mu izbjegne - vještičarstvo ovdje postaje metonimijom njezine žudnje. No, taj je nagovor povezan s dijelom koji nije prisutan u naracijama ni tužiteljice niti osumnjičenih, on je prešućen i skriven iako je svima poznat, a to je implicirani seksualni odnos koji prati “inicijaciju” u vještičju grupu, odnosno ugovor s vragom. Seksualni kontakt $s$ demonom odnosno vragom bio je standardnim dijelom ne samo vještičjega imaginarija usmene kulture, teoloških rasprava i inkvizitorskih priručnika nego i dijelom kaznenoga prava, pa i već navedene Kriminalne prakse koja je sadržavala i niz pitanja koja su se postavljala na torturi a koja su se ticala upravo spolnoga ugovora i đavoljega pečata na tijelu. ${ }^{19}$ Nema sumnje da je osobito u vrijeme masovnih progona, kada neka tijela postaju osobito opasnima ali i obilježenima, svima ili bar većini bio poznat način inicijacije, bilo propovijedima, pričama, predajama, tračevima ili pak javnim čitanjima optužnica protiv vještica, a čini se vrlo vjerojatnim da je bio poznat i Marijani Frajt. Stoga nagovor da stupi u vještičju službu doživljava istovjetnim sa seksualnim odnosom, odnosno postajanjem objektom žudnje, što rezultira histeričnom krizom a potom i optužbama jer žudnja za nezadovoljenom žudnjom mora biti očuvana. Colette Soler ističe kako je upravo za histerika karakteristično da uvijek optužuje Drugog - uvijek je riječ o propustu, pogrešci ili nedjelu Drugoga, za razliku od opsesivnog neurotika kod kojega je dominantan osjećaj krivnje (Soler 1996: 255). Tako Marijana Frajt mora optužiti nekoga za vlastitu žudnju, a uklanjanjem toga Drugoga, njezina žudnja može ostati netaknutom. Strah od približavanja pounutrenoj, posvojenoj žudnji Drugoga vodi Frajt prvo u bijeg k vlastitim roditeljima, a kada ni tamo ne nestaje strah, ona se odlučuje na radikalnu, fizičku eliminaciju žena iz najbliže joj okoline podnoseći tužbu protiv njih koja je u to doba značila istodobno i pritvor i torturu.

No, kako je prema Lacanu i postlacanovskoj psihoanalizi žudnja zapravo žudnja Drugoga, ili žudnja za žudnjom Drugoga, ili pak žudnja koja je istovjetna žudnji Drugoga, ${ }^{20}$ postavlja se pitanje tko je taj Drugi žudnje Marijane Frajt koji je potaknuo histerične simptome, a posljedično i sudski proces. Iz zapisnika, posebno iz dijela priče M. Frajt jasno je da su nagovori da se udruži s vješticama potekli prvo od njezina supruga, njegove majke i njezine sestre Dore, no za to razdoblje ne pripovijeda o vlastitim fizičkim poteškoćama, odnosno izostaje simptomatologija histerije. Poistovjećivanje ulaska u brak i postajanja objektom suprugove žudnje ona izjednačuje s vještičjom opasnošću, jer je jedan strah zamijenjen za drugi metonimijskim "klizanjem" označitelja, no to ipak ne izaziva ni pobunu ni bijeg. Zanimljivo je da se njezini simptomi aktiviraju tek dolaskom Marijane Vugrinec, sluškinje u kući suprugovih roditelja, "babe" koja je neprestano poziva da im se pridruži pri čemu joj obećava "da će imati više mlijeka, da će njeno žito svagdje biti bolje, što god će vidjeti da će biti njeno" (Bayer 1982: 688), odnosno jamči joj obilje i plodnost, što je, dakako, metafora odnosno analogija ženske prokreacije, tj. ženskih reproduktivnih moći.

${ }^{19} \mathrm{U}$ paragrafu 4 Kriminalne prakse prvih devet pitanja odnose se upravo na ugovor i demonski pečat (Bayer 1982: 568-569).

${ }^{20}$ Radi se o mogućim prijevodima Lacanova diktuma, "Le désir de l'homme, c'est le désir de l'Autre" (1964: 38), ako drugo de shvatimo kao genitiv subjekta, a kojim naglašava koekstenzivnost manjka i žudnje, tj. čovjekova je žudnja da ga Drugi žudi čime nastoji održati iluziju svoje cjelovitosti prianjanjem za žudnju Drugoga (usp. Fink 2009: 57-69). 
No, razlog pojave simptoma histerije kod Frajt dolaskom Marijane Vugrinec moguće je razumjeti i iz jedne naoko usputne opaske u zapisniku na koju se tijekom procesa nitko od ispitanih i optuženih ne vraća, a ključna je za razumijevanje mehanizama žudnje. Naime, podžupan Saić u pismu navodi da svekar Marijane Frajt tvrdi da su optužena Marijana Vugrinec i njegov sin, Brcko Smerdić bili ljubavnici:

Kada je ona odvedena, stao je svekar rečene snahe koji je sa sinom i ženom ostao pred nama u kući, govoriti da vidi i prepoznaje čarobnjačke čine na svojoj snahi, i da se boji da mu Marica nije i sina opčinila i u čarobnjaštvo zavela, pošto je njegov sin s rečenom Maricom više od dva mjeseca spavao. (Bayer 1982: 684)

Taj neobičan par - starije žene i mlađega muškarca koji se oformljuje ubrzo nakon dolaska služavke, ali i vjenčanja Smerdića i Frajt - potaknuo je strah i žudnju M. Frajt koji su se manifestirali na tijelu kao simptomi histerije, odnosno potaknuo je identifikaciju, koja je ključni trenutak žudnje, ${ }^{21}$ dviju žena uključenih u ljubavni trokut. Prva razina identifikacije odvija se na razini imaginarnoga jer se Frajt poistovjećuje s nekom značajkom Vugrinec - obećana plodnost usjeva, životinja itd. postala je metaforom ženske plodnosti kojoj je jamac bila upravo vještica Vugrinec. Premda su razlike među dvjema ženama brojne - jedna je mlada, drugu nazivaju “babom”, jedna je služavka dok druga zauzima nešto višu društvenu poziciju, različitoga su bračnoga statusa (za Vugrinec ne znamo je li udovica ili nikada nije bila udana), no ključna je razlika u njihovu potomstvu: Frajt nema djece, dok Vugrinec ima kćer, to jest ostvarila je društveno propisani "krajnji cilj" - prokreaciju. Tako Vugrinec za Marijanu Frajt predstavlja zavodljivu privlačnost, navještaj plodnosti, odnosno ono što Lacan naziva agalma - objekt privlačnosti koji uspijeva privući pozornost i zanimanje Drugoga, ono što pokreće žudnju (Lacan 2001: 167-182) - koji Frajt pokušava prisvojiti i pounutriti jer i ona sama žudi za žudnjom Drugoga (vlastita supruga), ali vjerojatno i stoga jer nastoji zadovoljiti i svoju žensku ulogu. No kako je žudnju nemoguće zadovoljiti, a u histeriji nije ni dopušteno, Frajt ne samo da odbija tjelesni kontakt i prokreaciju, ona želi i negativizaciju takvoga užitka (jouissance, koji ne podrazumijeva samo ugodu, nego može izazivati i užas i gađenje) kod Drugoga - vlastita supruga i njegove ljubavnice optužujući ih da su pripadnici vještičje sekte. Takvom optužbom ona ih nastoji eliminirati kako bi se zaštitila od vlastita manjka i od postajanja objektom tuđe žudnje, optužbom koja je u ovome slučaju rezultirala trima smrtima.

${ }^{21}$ Ovdje se referiram na Lacanovu analizu Freudova komentara jednoga sna prikazanog u Tumačenju snova. Riječ je o paradigmatskom slučaju histerije navedenom u Spisima, u dijelu "La direction de la cure et les principes de son pouvoir" (1966a: 62-123, posebno 97 i dalje), o snu "dovitljive mesarove žene", kako ju je nazvao Lacan. Razrađujući razine identifikacije Lacan dolazi do jezgre žudnje koja je u njegovom psihoanalitičkom tumačenju jedan od središnjih pojmova strukture subjektiviteta, a koju razlikuje od potrebe i zahtjeva. Potreba i zahtjev mogu biti zadovoljeni, dok žudnja ne može - ona nastaje u njihovu međuprostoru, ona je višak nastao artikuliranjem potrebe u zahtjev i njezino ishodište "nije odnos prema zbiljskom predmetu neovisnom o subjektu, nego prema fantazmi. Na zahtjev je nesvodljiva zbog toga što se nastoji nametnuti ne vodeći računa o jeziku i nesvjesnom Drugoga te traži da je Drugo apsolutno prizna" (Laplanche i Pontalis 1992: 512). 
Marijana Vugrinec umrla je u zatvoru od posljedica mučenja, a Magda Brcković i Marijana Brukec osuđene se na smrt 4. svibnja 1752. Samo je Marijana Fućkan, koja jedina nije bila ni u kakvim obiteljskim vezama s ostalim ženama iz istoga procesa, nakon ispitivanja puštena na slobodu, dok Brcko Smerdić nije ni bio osumnjičen za vještičarstvo.

\section{UMJESTO ZAKLJUČKA}

Službeni dokumenti iz doba masovnih progona vještica poput zapisnika sa suđenja, zakonskih propisa, kronika, teoloških rasprava iznimno su bogat repozitorij, između ostaloga, ranonovovjekih emocija i afekata, a iščitavanje tih tekstova nam omogućuje razumijevanje afektivnih/emotivnih praksi, atmosfera i politika koji su progonima dali okvir. Odnosno, omogućuju nam praćenje dinamike kulturnoga, društvenoga i ideološkoga hijerarhiziranja i kodiranja emocija, pri čemu se neke emocije u javnome diskursu promovira kao prihvatljive, dopuštene i poželjne dok se druge sankcionira i disciplinira, stvarajući pritom specifične afektivne atmosfere ili emotivne režime, kako ih naziva William Reddy (2001). U ovome sam radu koristila pojmove emocija i afekata kao sinonimne, bez stroge distinkcije kao različitih aspekata nekoga doživljaja ili iskustva kako je predlažu npr. afektivne znanosti (npr. Massumi 2002), a oslanjajući se ponajprije na latinski korijen riječi affectus, u značenju "dispozicija, raspoloženje, stanje uma ili tijela izazvano, potaknuto vanjskim utjecajem", i, dakako, na rad Sare Ahmed, Cultural Politics of Emotion (2014). Takav pristup emocijama/ afektima, čini mi se, najbolje naglašava i njihov individualni, osobni doživljaj i izvorište, tj. psihološko stanje pojedinca, ali i njihovu sociokulturnu uvjetovanost i oblikovanost, odnosno pojašnjava kako su emocije, kao objektno usmjerene i objektno potaknute (što je i psihoanalitičko polazište), istodobno i društvene i kulturne prakse. Stoga je u fokusu ovoga rada upravo kruženje ne samih emocija, nego ponajprije objekata emocija, točnije objekata straha, tragovi i otisci koje ti objekti ostavljaju u dodiru s drugima te kako se potom percepcija tih objekata povratno njima vraća i obilježuje ih, puni značenjima i mijenja ih $\mathrm{u}$ određenom sociokulturnom kontekstu. $U$ doba masovnih progona dominantna je (ili jedna od vladajućih) afektivna atmosfera straha u kojoj su, društvenim konsenzusom i ideološkim poticajima, glavnim objektom straha postala drukčija, već izvanjskim razlikama obilježena vještičja tijela koja su postala sinonimima za svaki objekt straha. Na jednome mikroprimjeru, zapisniku sa suđenja vješticama iz Križevaca i Zagreba, pri samome kraju masovnih progona u Hrvatskoj, nastojala sam pokazati kako tužiteljičina histerija, a koju razmatram kao pitanje straha od žudnje, a ne pitanje žudnje kao lacanovska psihoanaliza na koju se obilato oslanjam pri interpretaciji, metonimijskim pomakom označitelja postaje strahom od vještica. Tako individualno izvorište određene emocije, žudnje i straha od nje, odnosno histerije kao svojevrsne pobune protiv uloge žene kao objekta razmjene, a zbog nemogućnosti da se pobuna drukčije iskaže jer je društveno neprihvatljiva i nedopuštena, traži svoj društveno prihvatljiv iskaz i objekt te se u pripovijedanju iskazuje kao strah od vještica, koje društveni ugovor podržava i odobrava. 
Percepcija, doživljaj vještičjega tijela kao označenoga i opasnoga utjecala je na tijelo tužiteljice koje je također postalo označeno - paralizom, konvulzijama, afazijom, a što je u kruženju značenja povratno utjecalo na tijela optuženih žena od kojih su sve podvrgnute torturi, a tri su osuđene na smrt, prvo vješanjem, a potom i potpunim uništenjem tijela - spaljivanjem.

Uronjenost u afektivne atmosfere i njihovo prihvaćanje, kao i dijeljenje objekata emocija, čini emocije snažnima u stvaranju društvenih veza i ugovora, no ponekad i sa smrtnim posljedicama.

\section{NAVEDENA LITERATURA I IZVORI}

Ahmed, Sara. 2014 (2004). The Cultural Politics of Emotion. Edinburgh: Edinburgh University Press. Anderson, Ben. 2009. "Affective Atmospheres". Emotion, Space and Society 2/2: 77-81.

Bayer, Vladimir. 1982. Ugovor s đavlom. Zagreb: Zora (treće izdanje).

Borossa, Julia. 2003. Histerija. Zagreb: Naklada Jesenski i Turk.

Bronfen, Elisabeth. 1998. The Knotted Subject. Hysteria and Its Discontents. Princeton: Princeton University Press.

Charcot, Jean-Martin i Paul Richer. 1887. Les Démoniaques dans l'Art. Paris: Adrien Delahaye et Emile Lecrosnier. Dostupno na: https://archive.org/stream/lesdmoniaquesdaOOrichgoog\#page/n5/mode/2up.

Cixous, Hélène. 1976. Portrait de Dora. Pariz: Editions des Femmes.

Clément, Catherine. 1979. L'Opéra ou la Defaite de la Femme. Pariz: Grasset.

Didi-Huberman, Georges. 2003. Invention of Hysteria. Charcot and the Photographic Iconography of Salpêtrière. Cambridge, MA, London: MIT Press.

Elias, Norbert. 1978. i 1982. The Civilizing Process. Sociogenetic and Psychogenetic Investigations, 1-2. 1: The History of Manners (1978); 2: State Formation and Civilization (1982). Oxford: Oxford University Press.

Elliot, Anthony. 2012. Uvod u psihoanalitičku teoriju. Zagreb: AGM.

Elmer, Peter. 2007. "Science, Medicine and Witchcraft". U Witchcraft Historiography. Jonathan Barry i Owen Davies, ur. Basingstoke, New York: Palgrave Macmillan. [https://doi. org/10.1057/9780230593480_3]

Evans, Dylan. 1996. An Introductory Dictionary of Lacanian Psychoanalysis. London, New York: Routledge.

Evans, Martha Noel. 1991. Fits and Starts. A Genealogy of Hysteria in Modern France. Ithaca: Cornell University Press.

Ferber, Sarah. 1997. "Charcot's Demons. Retrospective Medicine and Historical Diagnosis in the Writings of the Salpêtrière School". U Illness and Healing Alternatives in Western Europe. Gijswijt-Hofstra, Marijke, Hilary Marlan i Hans de Waardt, ur. London, New York: Routledge, 120-140.

Fink, Bruce. 2009. Lakanovski subjekt. Između jezika i jouissance. Zagreb: Kruzak.

Foucault, Michel. 1999. Les Anormaux. Pariz: Editions de Seuil/Gallimard.

Freud, Sigmund. 1940-1952. "Ein Fall von hypnotischer Heilung". Gesammelte Werke, chronologisch geordnet, 18. Marie Bonaparte et al., ur. London: Imago, 1: 6. 
Frevert, Ute. 2011. Emotions in History - Lost and Found. Budapest, New York: Central European University Press. [https://doi.org/10.7829/9786155053344Frevert]

Gilman, Sander L., Helen King, Roy Porter, G. S. Rousseau i Elaine Showalter. 1993. Hysteria Beyond Freud. Berkeley: University of California Press.

Grose, Anouchka, ur. 2016. Hysteria Today. London: Karnac Books.

Irigaray, Luce. 1985. (1974. prvo izdanje na francuskom). "La Mystérique". Speculum of the Other Woman. Ithaca, N. Y.: Cornell University Press.

Israël, Lucien. 1976. L'hysterique, le sexe, et le médecin. Pariz: Masson.

Kounine, Lara i Michael Ostling, ur. 2016. Emotions in the History of Witchcraft. London: Palgrave Macmillan.

Lacan, Jacques. 1960/1961. Le séminaire - Livre 8: Le transfert. J.-A. Miller, ur. Pariz: Seuil.

Lacan, Jacques. 1999. Écrits I. (prvo izdanje 1966.). Pariz: Sevil.

Lacan, Jacques. 1999a. Écrits II. (prvo izdanje 1966.). Pariz: Seuil.

Lacan, Jacques. 2001. “Edipov kompleks”. Tvrđa 1-2.

Laplanche, J. i J.-B. Pontalis. 1992. Rječnik psihoanalize. Zagreb: August Cesarec, Naprijed.

Massumi, Brian. 2002. Parables for the Virtual. Movement, Affect, Sensation. Durham: Duke University Press. [https://doi.org/10.1215/9780822383574]

Matijašević, Željka. 2005. “Histerija i rod”. Zagreb: Filozofska istraživanja 4: 829-839.

Micale, Mark S. 1995. Approaching Hysteria. Disease and Its Interpretations. Princeton: Princeton University Press.

Midelfort, H. C. Erik. 2002. "Charcot, Freud and the Demons". U Werewolves, Witches and Wandering Spirits. Traditional Belief and Folklore in Early Modern Europe. Kathryn A. Edwards, ur. Kirksville: Truman State University Press.

Midelfort, Eric H. 2011. "Witch Craze? Beyond the Legends of Panic". Magic, Ritual, and Witchcraft 6/1: 11-33. [https://doi.org/10.1353/mrw.2011.0011]

Ouerd, Michèle. 1992. "Dans la forge à cauchemars mythologiques. Sorcières, practiciennes et hystériques". Les cahiers de Fontenay 11-12: 103-58.

Plamper, Jan. 2015. The History of Emotions. An Introduction. Oxford: Oxford University Press.

Porter, Roy. 2002. Madness. A Brief History. Oxford: Oxford University Press.

Reddy, William. 2001. The Navigation of Feeling. A Framework for the History of Emotions. Cambridge: Cambridge University Press. [https://doi.org/10.1017/CBO9780511512001]

Ricoeur, Paul. 2005. O tumačenju. Ogled o Freudu. Zagreb: Ceres.

Roper, Lyndal. 2006. Witch Craze. Terror and Fantasy in Baroque Germany. New Haven, London: Yale University Press.

Showalter, Elaine. 1985. The Female Malady. Women, Madness, and English Culture, 1830 - 1980. New York: Pantheon Books.

Soler, Colette. 1992. "Hystory and Hysteria. The Witty Butcher's Wife". Newsletter of the Freudian Field 6/1-2: 16-33.

Soler, Colette. 1996. "Hysteria and Obsession". Reading Seminars I and II. Lacan's Return to Freud. Richard Feldstein, Bruce Fink i Maire Jaanus, ur. Albany: Suny Press.

Stearns, Peter N. i Carol Z. Stearns. 1985. "Clarifying the History of Emotions and Emotional Standards". The American Historical Review 90/4: 813-836. [https://doi.org/10.2307/1858841] 
Trevor-Roper, H. R. 1969. The European Witch-Craze of the Sixteenth and Seventeenth Centuries. Harmondsworth, Middlesex: Viking.

Verhaeghe, Paul. 2001. "Subject and Body. Lacan's Struggle with the Real". Beyond Gender. From Subject to Drive. New York: Other Press, 65-97.

Wetherell, Margaret. 2013. "Feeling Rules, Atmospheres and Affective Practice. Some Reflections on the Analysis of Emotional Episodes". U Privilege, Agency and Affect. Understanding the Production and Effects of Action. Claire Maxwell i Peter Aggleton, ur. London: Palgrave Macmillan. [https://doi. org/10.1057/9781137292636_13]

\section{FEAR, LUST, HYSTERIA: NOTES ON A WITCH TRIAL RECORD}

This text presents a discussion of the history of one course in historiographic and anthropological studies of mass witch persecutions, namely the course that considers them a psychopathological phenomenon, and considers the Early Modern Period a period of madness - hysteria, mass hysteria, fantasy. Such studies are based on the tradition of medical, neurological, psychiatric and psychoanalytical work which started with the psychopathologization of women accused of witchcraft, where Charcot and Freud play a significant role. An example of a witch trial record from a trial held in Križevci in 1751 and 1752 is discussed from the point of view of hysteria as a sort of lust and fear in relation to the dominant affective policy and the affective atmosphere, indicating an inseparability between personal fears and anxieties and social dynamics.

Keywords: fear, hysteria, lust, affective policy, affective atmospheres, witches, Croatia, 18th century 